Volume -X, Issue -01, January-June, 2015

\title{
Effects of Customers' Relational Benefits on Development of Banking Industry: An Empirical Study on Some Commercial Banks in Khulna City of Bangladesh
}

\author{
RUMANA PERVEEN* \\ MD. RABIUL ISLAM ${ }^{* *}$
}

\begin{abstract}
This research is conducted to identify the benefits that customers receive as a result of maintaining long-term relation with commercial banks. Necessary data were collected from 262 respondents of different commercial banks of Khulna city of Bangladesh. Multiple regressions with SPSS were applied for data analysis. Customers' relational benefits can be categorized into three distinct benefit types: confidence, social and special treatment benefits. The results have showed that confidence benefit is the most pronounced factor for customers of banks. The findings have also revealed that confidence benefits and social benefits have statistically significant effect on customers' retention which is the key building block of developing banking industry in Bangladesh.
\end{abstract}

Key words: Confidence benefit, Social benefit, Special treatment benefit, Customer's retention, Banking industry.

\section{INTRODUCTION}

Relationship marketing is the key factor of customers' retention. It is a strategy to build profitable long-term relation with customers. As intense competition exists in the banking industry in Bangladesh so retaining existing customers has become a challenge for the commercial banks. Customers' retention is possible by providing different benefits to them categorized as confidence benefit, social benefit and special treatment benefit (Zeithaml et al.,

\footnotetext{
*Senior Lecturer in Marketing, Department of Business Administration, Northern University Bangladesh, E-mail: rumana_parveen@yahoo.com.

**Assistant Professor of CSE, Department of Business Administrative, Northern University Bangladesh, E-mail: rabi@ yahoo.com
} 
2011). To cope with the intense competition the commercial banks are trying to give more concentration on ensuring relational benefits. This research tries to explore different types of benefits that influence relationship commitment which plays a significant role in the development of banking industry in Bangladesh especially in Khulna city which is the third largest city in Bangladesh.

\section{LITERATURE REVIEW}

Chen and $\mathrm{Hu}$ (2010) in the article on "The effect of relational benefits on perceived value in relation to customer loyalty: An empirical study in the Australian coffee outlets industry" collected responses from 949 customers of coffee outlets and found that relational benefits have direct effect on perceived value and customer loyalty and indirect effect on loyalty via perceived value.

Chen and $\mathrm{Hu}$ (2013) in the article on "The mediating role of relational benefit between service quality and customer loyalty in airline industry" have used 403 respondents and revealed that service quality has positive impacts on relational benefit and customer loyalty in the airline industry and the interaction between the consumer and service provider was ongoing (relational) rather than one-off (transactional).

Conze et al., (2010) in the article on "Relationship intention as a mediator between relational benefits and customer loyalty in the tour operator industry" used measurement model based on a confirmatory factor analysis using LISREL with a sample of 1,702 tour operator customers. The findings showed that intention of a customer to invest in a relationship is dependent on the perceived level of relationship benefits and the buying behavior of customers is influenced by the perceived relational benefits.

Gremler and Bitner (1998) in the article "Relational benefits in services industries: The customer's perspective" found that consumer relational benefits can be categorized into three distinct benefit types: confidence, social, and special treatment benefits. Confidence benefits are received more and rated as more important than the other relational benefits by consumers, followed by social and special treatment benefits, respectively.

Han and Kim (2009) in the paper on "Outcomes of relational benefits: restaurant customers' perspective" showed that there was indirect link between the special treatment benefit and perceived value and social, special treatment, and confidence benefits appeared to boost perceived price and value.

Kim and Ok (2009) in the paper on "The effects of relational benefits on customers' perception of favorable inequity, affective commitment, and repurchase intention in full-service restaurants" found that relational benefits (including confidence benefits, social benefits, and special treatment benefits) 
affect customers' perceptions of favorable inequity and affective commitment, and thus ultimately affect customer retention.

Molina et al., (2007) in "Relational benefits and customer satisfaction in retail banking" have identified the impact of relational benefits by collecting responses from 204 bank customers and used structural equation model and revealed that confidence benefits have a direct, positive effect on the satisfaction of customers with their bank. However, special treatment benefits and social benefits did not have any significant effects on satisfaction in a retail banking environment.

Patterson and Smith (2001) in the article on "Relationship benefits in service industries: a replication in a Southeast Asian context" explained the benefits that customers receive from maintaining long term relationship with service providers by using 155 respondents from Thailand and Bangkok and revealed that empirical research is not sufficient to measure marketing phenomena.

\section{OBJECTIVES OF THE RESEARCH}

This research paper aims to achieve the followings objectives:

i. To identify the effects of relational benefits (confidence, social, special treatment benefits) on customers' retention.

ii. To identify which relational benefit has the most significant effect on customers' retention.

iii. To evaluate whether there is any effect of customers' retention on the development of banking industry in Bangladesh.

\section{RESEARCH METHODOLOGY}

This study has been conducted mainly based on primary data which have been collected from structured questionnaire survey of 262 respondents from different commercial banks of Khulna by using random sampling method. The questionnaire has been developed by taking help from a marketing textbook named as Services Marketing (Zeithaml et. al., 2011). The primary data were collected in the period, February 1 to 28, 2015. This study considers the following three broad factors to measure the customers' retention: confidence benefit, social benefit and special treatment benefit. These factors have many sub-factors to get a detailed viewpoint about the customer's retention. The questionnaire has been developed by using 5 point Likert-type scale consisting of assigned values between 1 to 5 where value $1=$ Strongly disagreed, $2=$ Disagreed, $3=$ Neutral, 4= Agreed, 5= Strongly Agreed for the asked questions. Secondary data have been collected from articles of different journals, text books, websites 
etc. Collected data have been analyzed through descriptive statistics (frequency, percentage, mean, standard deviation) and multiple regressions by using SPSS version no.16. To achieve the objectives mentioned above the following hypotheses have been developed:

$\mathrm{H}_{0}$ : There is no statistically significant effect of confidence benefits provided by banks on customers' relationship commitment toward banking sectors.

$\mathrm{H} 1_{\mathrm{a}}$ : There is statistically significant effect of confidence benefit provided by banks on customers' relationship commitment toward banking sectors.

$\mathrm{H} 2_{0}$ : There is no statistically significant effect of social benefit provided by banks on customers' relationship commitment toward banking sectors.

$\mathrm{H} 22_{\mathrm{a}}$ : There is statistically significant effect of social benefit provided by banking sectors on customers' relationship commitment toward banking sectors.

$\mathrm{H} 3_{0}$ : There is no statistically significant effect of special treatment provided by banks on customers' relationship commitment toward banking sectors.

$\mathrm{H} 3_{\mathrm{a}}$ : There is statistically significant effect of special treatment benefit provided by banks on customers' relationship commitment toward banking sectors.

$\mathrm{H} 4_{0}$ : There is no statistically significant effect of any relational benefit provided by banks on customers' relationship commitment toward banking sectors.

$\mathrm{H} 4_{\text {a: }}$ There is statistically significant effect of relational benefit provided by banks on customers' relationship commitment toward banking sectors.

$\mathrm{H} 5_{0}$ : There is no statistically significant effect of customers' relationship commitment on the development of banking industry in Bangladesh.

$\mathrm{H} 5_{\mathrm{a}}$ : There is statistically significant effect of customers' relationship commitment on the development of banking industry in Bangladesh.

For multiple regressions the following model has been used: $Y=a_{0}+b_{1} x_{1}+b_{2} x_{2}+\ldots \ldots \ldots .+b_{n} x_{n}$

Here, $Y=$ dependent factor, $\mathrm{a}_{0}=$ constant, $x_{1}, x_{2}, \ldots \ldots \ldots \ldots \ldots \ldots x_{\mathrm{n}}$ are the independent factors and $b_{1}, b_{2}, \ldots \ldots b_{n}$ are the coefficients of the independent factors. Here for hypothesis number. 1-4 dependent factor is customers' relationship commitment and for hypothesis number 5 dependent factor is development of banking industry in Bangladesh. 


\section{RELATIONAL BENEFITS}

Customers are more likely to stay in a relationship when the gets (quality, satisfaction, specific benefits) exceed the gives (monetary and nonmonetary costs). When the organization can consistently deliver value from the customer's point of view, clearly the customer benefits and has an incentive to stay in relationship (Zeithaml et al., 2011). A key principle of relationship marketing is the retention of customers through different benefits. Dawkins and Reichheld (1990) calculated a company's "customer retention rate". This is simply the percentage of customers at the beginning of the year that are still customers by the end of the year. In accordance with this statistic, an increase in retention rate from $80 \%$ to $90 \%$ is associated with a doubling of the average life of a customer relationship from 5 to 10 years. This ratio can be used to make comparisons between products, between market segments, and over time (en.wikipedia.org). Relational benefits can be categorized into confidence benefit, social benefit and special treatment benefit. Confidence benefits comprise feelings of trust and confidence in the provider along with a sense of anxiety and comfort in knowing what to expect. Customers develop a sense of familiarity over the time with service provider and enjoy service with them as a social benefit. On the other hand customers get preferential treatment such as special price discount as a special treatment benefit (Zeithaml et al., 2011).

\section{EMPIRICAL FINDINGS AND ANALYSIS}

Demographic characteristics (Table I in Appendix) of the respondents reveal that the majority of the respondents $(26 \%)$ are in between 41 and 50 years, 24\% between 51 and 60 years and $19.8 \%$ between 31 and 40years, only $19.5 \%$ is above 60 years. The maximum respondents are male $(61.5 \%)$ and only $38.5 \%$ of the respondents are female, while $59.9 \%$ of them are married and $35.5 \%$ are unmarried. The maximum respondents have chosen conventional bank (60.3\%) than Islamic bank (39.7\%). Most of the respondents use current accounts (41.6\%) and $36.3 \%$ and $22.1 \%$ use savings and term accounts respectively. The maximum respondents $(40.5 \%)$ have banking experience of four years and few (12.6\%) have banking experience more than four years. Maximum respondents are well educated. Here, $34 \%$ has passed graduate and postgraduate level, $12.6 \%$ has completed HSC level and $4.6 \%$ falls into SSC passed, but only $14.5 \%$ respondents have completed M.Phil/ $\mathrm{PhD}$. degree. Most of the respondents $(31.3 \%)$ are businessman and a few of them $(5.3 \%)$ are bankers. Most of them (34.7\%) earn monthly Tk. 30,001-Tk. 40,000 and few of them (9.2\%) earn less than Tk.10,000. 
TABLE II

RANKING IMPORTANCE OF RELATIONAL BENEFITS

\begin{tabular}{|c|c|c|c|c|c|c|}
\hline Confidence Benefit & $\mathrm{N}$ & Minimum & Maximum & Mean & Ranking & $\begin{array}{c}\text { Std. } \\
\text { Deviation }\end{array}$ \\
\hline $\begin{array}{l}\text { The bank management is } \\
\text { honest and reliable }\end{array}$ & 262 & 1.00 & 5.00 & 3.7290 & 3 & 1.16750 \\
\hline $\begin{array}{l}\text { You feel released and } \\
\text { relieved after accepting } \\
\text { service }\end{array}$ & 262 & 1.00 & 5.00 & 3.5458 & 4 & 1.29092 \\
\hline The bank gives best service & 262 & 1.00 & 5.00 & 3.7672 & 2 & 1.17900 \\
\hline $\begin{array}{l}\text { The bank protects client's } \\
\text { privacy }\end{array}$ & 262 & 1.00 & 5.00 & 3.9122 & 1 & 1.20500 \\
\hline \multicolumn{7}{|l|}{ Social Benefit } \\
\hline $\begin{array}{l}\text { Employees are nice and } \\
\text { friendly }\end{array}$ & 262 & 1.00 & 5.00 & 3.7595 & 2 & 1.21588 \\
\hline $\begin{array}{l}\text { Employees recognize you by } \\
\text { first or last name }\end{array}$ & 262 & 1.00 & 5.00 & 3.8244 & 1 & 1.22541 \\
\hline You enjoy banking with them & 262 & 1.00 & 5.00 & 3.7137 & 3 & 1.24650 \\
\hline \multicolumn{7}{|l|}{ Special Treatment Benefit } \\
\hline $\begin{array}{l}\text { Banks provide service more } \\
\text { quickly than others }\end{array}$ & 262 & 1.00 & 5.00 & 3.8122 & 1 & 1.10500 \\
\hline $\begin{array}{l}\text { The banks give you more } \\
\text { service related information } \\
\text { than others }\end{array}$ & 262 & 1.00 & 5.00 & 3.7595 & 3 & 1.21588 \\
\hline $\begin{array}{l}\text { Banks provide more facilities } \\
\text { to you }\end{array}$ & 262 & 1.00 & 5.00 & 3.7672 & 2 & 1.17900 \\
\hline Valid N (list wise) & 262 & & & & & \\
\hline
\end{tabular}

Source: Field Survey, February 2015

In confidence benefit respondents give the most importance in protecting client's privacy as it has the highest mean value (3.9122). The mean value of providing best service is 3.7622 . Under Social benefit, the recognizing capacity of employees' by client's first or last name has the highest mean value (3.8244). Respondents think that friendliness of employees is also important for customer's retention as it has the second highest mean value (3.7595) but enjoyable banking has less importance on customers' retention with mean value (3.7137). Under special treatment benefit, there are three variables. Among them providing quick 
service is the most important factor of customers' retention with highest mean value (3.8122) and providing more facilities also influence customers' retention with mean value (3.7672).

TABLE III

REGRESSION BETWEEN CONFIDENCE BENEFIT AND CUSTOMERS' RELATIONSHIP COMMITMENT TOWARD BANKING SECTORS.

\begin{tabular}{c|c|c|c|c}
\hline \multicolumn{5}{c}{ Model Summary 1 } \\
\hline Model & $\mathrm{R}$ & R Square & Adjusted R Square & Std. Error of the Estimate \\
\hline 1 & $.312^{\mathrm{a}}$ & .097 & .083 & .78592 \\
\hline
\end{tabular}

a. Predictors: (Constant), Client's privacy, honesty and reliability, best service, feeling released and relieved.

\begin{tabular}{cl|c|c|c|c|c}
\hline \multicolumn{7}{c}{ ANOVA $^{\mathbf{b}}$} \\
\hline \multicolumn{1}{c}{ Model } & Sum of Squares & $\mathrm{df}$ & Mean Square & $\mathrm{F}$ & Sig. \\
\hline 1 & Regression & 17.110 & 4 & 4.277 & 6.925 & $.000^{\mathrm{a}}$ \\
& Residual & 158.741 & 257 & .618 & & \\
& Total & 175.851 & 261 & & \\
\hline
\end{tabular}

a. Predictors: (Constant), Client's privacy, honesty and reliability, best service, feeling released and relieved.

b. Variable: Customers' relationship commitment toward banking sectors.

\begin{tabular}{|c|c|c|c|c|c|c|}
\hline \multicolumn{7}{|c|}{ Coefficients $^{\mathrm{a}}$} \\
\hline & \multirow[t]{2}{*}{ Model } & \multicolumn{2}{|c|}{$\begin{array}{l}\text { Unstandardized } \\
\text { Coefficients }\end{array}$} & \multirow{2}{*}{$\begin{array}{c}\begin{array}{c}\text { Standardized } \\
\text { Coefficients }\end{array} \\
\text { Beta }\end{array}$} & \multirow[t]{2}{*}{$\mathrm{t}$} & \multirow[t]{2}{*}{ Sig. } \\
\hline & & $\mathrm{B}$ & Std. Error & & & \\
\hline \multirow[t]{5}{*}{1} & (Constant) & 3.174 & .263 & & 12.076 & .000 \\
\hline & $\begin{array}{l}\text { The bank management is } \\
\text { honest and reliable }\end{array}$ & .153 & .042 & .217 & 3.626 & .000 \\
\hline & $\begin{array}{l}\text { You feel released and } \\
\text { relieved after accepting } \\
\text { service }\end{array}$ & .005 & .042 & .008 & .126 & .900 \\
\hline & $\begin{array}{l}\text { The bank gives best } \\
\text { Service }\end{array}$ & -.039 & .044 & -.055 & -.884 & .378 \\
\hline & $\begin{array}{l}\text { The bank protects Client's } \\
\text { Privacy }\end{array}$ & .160 & .043 & .234 & 3.736 & .000 \\
\hline
\end{tabular}

a. Dependent Variable: Customers' relationship commitment toward banking sectors. 
The above model summary 1 indicates that there remain a correlation between independent variables of confidence benefits (Client's Privacy, honesty and reliability, best service, feeling released and relieved.) and dependent variable (Customers' relationship commitment). At 5\% significance level the correlation is $31.2 \%$. The value of adjusted R Square is 0.083 that means $8.3 \%$ of dependent variable can be explained by the independent variables. From ANOVA test, it can be remarked that there is a statistically significant effect of honesty and reliability and protecting clients' privacy on customers' retention because the significance level of these variables is less than $5 \%$ but there is no statistically significant effect of other two variables because the significance level of these variables is greater than $5 \%$. Hence $\mathrm{H} 1_{0}$ is rejected and $\mathrm{H} 1_{\mathrm{a}}$ is accepted and the regressions equation will be:

$$
Y_{t}=a_{0}+b_{1} x_{1}+b_{2} x_{2}+\ldots \ldots \ldots+b_{n} x_{n}
$$

So, Customers' relationship commitment $=3.174+(.153)$ Honesty and Reliability + (.005) Released and Relieved + (-.039) Best Service+ (.160) Clients' Privacy.

TABLE IV

REGRESSION BETWEEN SOCIAL BENEFIT AND CUSTOMERS' RELATIONSHIP COMMITMENT TOWARD BANKING SECTORS.

\begin{tabular}{|c|c|c|c|c|c|}
\hline \multicolumn{6}{|c|}{ Model Summary 2} \\
\hline Model & $\mathrm{R}$ & R Square & $\begin{array}{l}\text { Adjusted R } \\
\text { Square }\end{array}$ & \multicolumn{2}{|c|}{ Std. Error of the Estimate } \\
\hline 1 & $.292^{\mathrm{a}}$ & \multicolumn{2}{|l|}{.085} & \multicolumn{2}{|c|}{.78960} \\
\hline \multicolumn{6}{|c|}{$\begin{array}{l}\text { a. Predictors: (Constant), enjoy banking, nice and friendly employees, recognizing by first or last } \\
\text { name. }\end{array}$} \\
\hline \multicolumn{6}{|c|}{ ANOVA $^{b}$} \\
\hline Model & Sum of Squares & df & Mean Square & $\mathrm{F}$ & Sig. \\
\hline 1 Regression & 14.998 & 3 & 4.999 & 8.019 & $.000^{\mathrm{a}}$ \\
\hline Residual & 160.853 & 258 & .623 & & \\
\hline Total & 175.851 & 261 & & & \\
\hline
\end{tabular}

a. Predictors: (Constant), enjoy banking, nice and friendly employees, recognizing by first or last name.

b. Dependent Variable: Customers' relationship commitment toward banking sectors. 


\begin{tabular}{|c|c|c|c|c|c|c|}
\hline \multicolumn{7}{|c|}{ Coefficients $^{\mathrm{a}}$} \\
\hline \multirow{2}{*}{\multicolumn{2}{|c|}{ Model }} & \multicolumn{2}{|c|}{$\begin{array}{l}\text { Unstandardized } \\
\text { Coefficients }\end{array}$} & \multirow{2}{*}{$\begin{array}{c}\begin{array}{c}\text { Standardized } \\
\text { Coefficients }\end{array} \\
\text { Beta }\end{array}$} & \multirow[t]{2}{*}{$\mathrm{t}$} & \multirow[t]{2}{*}{ Sig. } \\
\hline & & B & Std. Error & & & \\
\hline \multirow[t]{4}{*}{1} & (Constant) & 3.503 & .235 & & 14.901 & .000 \\
\hline & $\begin{array}{l}\text { Employees are nice } \\
\text { and friendly }\end{array}$ & -.034 & .040 & -.051 & -.851 & .396 \\
\hline & $\begin{array}{l}\text { Employees } \\
\text { recognize you by } \\
\text { first or last name }\end{array}$ & .176 & .041 & .263 & 4.274 & .000 \\
\hline & $\begin{array}{l}\text { You enjoy banking } \\
\text { with them }\end{array}$ & .052 & .041 & .079 & 1.283 & .201 \\
\hline
\end{tabular}

a. Dependent variable: Customers' relationship commitment toward banking sectors.

The above model summary 2 indicates that there remain a correlation between independent variables of social benefits (enjoy banking, nice and friendly employees, recognizing by first or last name) and dependent variable (Customers' relationship commitment). At 5\% significance level the correlation is $29.2 \%$. The value of adjusted R Square is 0.075 . From ANOVA test, it can be remarked that there is a statistically significant effect of recognizing capacity of employees by client's first or last name on customers' retention because the significance level of this variable is less than $5 \%$ but there is no statistically significant effect of other two variables because the significance level of these variables are greater than $5 \%$. Hence $\mathrm{H} 2_{0}$ is rejected and $\mathrm{H} 2_{\mathrm{a}}$ is accepted and the regressions equation will be:

$$
Y_{t}=a_{0}+b_{1} x_{1}+b_{2} x_{2}+\ldots \ldots \ldots+b_{n} x_{n}
$$

So, Customers' relationship commitment $=3.503+(-.034)$ nice and friendly $+(.176)$ recognizing by first or last name $+(.052)$ enjoy banking.

TABLE V

\section{REGRESSION BETWEEN SPECIAL TREATMENT BENEFIT AND CUSTOMERS' RELATIONSHIP COMMITMENT TOWARD BANKING SECTORS.}

\begin{tabular}{c|c|c|c|c}
\hline \multicolumn{5}{c}{ Model Summary 3 } \\
\hline Model & $\mathrm{R}$ & R Square & Adjusted R Square & $\begin{array}{c}\text { Std. Error of the } \\
\text { Estimate }\end{array}$ \\
\hline 1 & $.216^{\mathrm{a}}$ & .047 & .036 & .81940 \\
\hline
\end{tabular}

a. Predictors: (Constant), more facilities, service related information, quick service. 


\begin{tabular}{|c|c|c|c|c|c|c|}
\hline \multicolumn{7}{|c|}{ Model Summary 3} \\
\hline Model & $\mathrm{R}$ & R Square & \multicolumn{2}{|c|}{ Adjusted R Square } & \multicolumn{2}{|c|}{$\begin{array}{l}\text { Std. Error of the } \\
\text { Estimate }\end{array}$} \\
\hline 1 & $.216^{\mathrm{a}}$ & .047 & \multicolumn{2}{|c|}{.036 } & \multicolumn{2}{|c|}{.81940} \\
\hline \multicolumn{7}{|c|}{ ANOVA $^{b}$} \\
\hline \multicolumn{2}{|c|}{ Model } & Sum of Squares & $\mathrm{df}$ & $\begin{array}{l}\text { Mean } \\
\text { Square }\end{array}$ & $\mathrm{F}$ & Sig. \\
\hline \multirow[t]{3}{*}{1} & ession & 8.488 & 3 & 2.829 & 4.214 & $.006^{\mathrm{a}}$ \\
\hline & dual & 173.226 & 258 & .671 & & \\
\hline & & 181.714 & 261 & & & \\
\hline
\end{tabular}

a. Predictors: (Constant), more facilities, service related information, quick service.

b. Dependent Variable: Customers' relationship commitment toward banking sectors.

\begin{tabular}{|c|c|c|c|c|c|c|}
\hline \multicolumn{7}{|c|}{ Coefficients $^{\mathrm{a}}$} \\
\hline & \multirow[t]{2}{*}{ Model } & \multicolumn{2}{|c|}{$\begin{array}{l}\text { Unstandardized } \\
\text { Coefficients }\end{array}$} & \multirow{2}{*}{$\begin{array}{c}\begin{array}{c}\text { Standardized } \\
\text { Coefficients }\end{array} \\
\text { Beta }\end{array}$} & \multirow[t]{2}{*}{$\mathrm{t}$} & \multirow[t]{2}{*}{ Sig. } \\
\hline & & B & Std. Error & & & \\
\hline \multirow[t]{4}{*}{1} & (Constant) & 3.938 & .254 & & 15.515 & .000 \\
\hline & $\begin{array}{l}\text { Banks provide service } \\
\text { more quickly than } \\
\text { others }\end{array}$ & .149 & .043 & .215 & 3.476 & .001 \\
\hline & $\begin{array}{l}\text { The banks give you } \\
\text { more service related } \\
\text { information than } \\
\text { others }\end{array}$ & -.048 & .042 & -.070 & -1.134 & .258 \\
\hline & $\begin{array}{l}\text { Banks provide more } \\
\text { facilities to you }\end{array}$ & -.031 & .044 & -.043 & -.701 & .484 \\
\hline
\end{tabular}

a. Dependent Variable: customers' retention

The above model summary 3 indicates that there remain a correlation between independent variables of special treatment benefits (more facilities, service related information, quick service) and dependent variable (Customers' relationship commitment). At 5\% significance level the correlation is $21.6 \%$. The value of adjusted R Square is 0.036 . From ANOVA test, it can be remarked that there is a statistically significant effect of providing service quickly than others on customers' relationship commitment because the significance level of this variables is less than $5 \%$ but there is no statistically significant effect of other two 
variables because the significance level of these variables are greater than $5 \%$. Hence $\mathrm{H} 3_{0}$ is rejected and $\mathrm{H} 3_{\mathrm{a}}$ is accepted and the regressions equation will be:

$$
Y_{t}=a_{0}+b_{1} x_{1}+b_{2} x_{2}+\ldots \ldots \ldots+b_{n} x_{n}
$$

So, Customers' relationship commitment $=3.938+(.149)$ quick service+ $(-$ $.048)$ service related information+ (-.031) more facilities.

TABLE VI

REGRESSION BETWEEN RELATIONAL BENEFIT AND CUSTOMERS' RELATIONSHIP COMMITMENT.

\begin{tabular}{c|c|c|c|c}
\hline \multicolumn{4}{c}{ Model Summary 4 } \\
\hline Model & $\mathrm{R}$ & R Square & Adjusted R Square & Std. Error of the Estimate \\
\hline 1 & $.242^{\mathrm{a}}$ & .059 & .048 & .81420 \\
\hline
\end{tabular}

a. Predictors: (Constant), Confidence Benefit, Social Benefit. Special Treatment Benefit

\begin{tabular}{rr|r|r|r|r|r}
\hline \multicolumn{7}{c}{ ANOVA $^{\mathbf{b}}$} \\
\hline & Model & Sum of Squares & df & Mean Square & F & \multicolumn{1}{c}{ Sig. } \\
\hline 1 & Regression & 10.681 & 3 & 3.560 & 5.371 & $.001^{\text {a }}$ \\
& Residual & 171.032 & 258 & .663 & & \\
& Total & 181.714 & 261 & & & \\
\hline
\end{tabular}

a. Predictors: (Constant), Confidence benefit, Social benefit ,Special treatment benefit,

b. Dependent Variable: Customers; relationship commitment

\begin{tabular}{l|c|c|c|c|c}
\hline \multicolumn{1}{c}{ Model } & \multicolumn{5}{c}{ Coefficients $^{\mathrm{a}}$} \\
& Unstandardized Coefficients & $\begin{array}{c}\text { Standardized } \\
\text { Coefficients }\end{array}$ & $\mathrm{t}$ & Sig. \\
\cline { 2 - 5 } & $\mathrm{B}$ & Std. Error & Beta & & \\
\hline $1 \quad$ (Constant) & 3.258 & .346 & & 9.407 & .000 \\
Confidence Benefit & .171 & .080 & .150 & 2.138 & .033 \\
Social Benefit & .208 & .076 & .200 & 2.719 & .007 \\
$\begin{array}{l}\text { Special Treatment } \\
\text { Benefit }\end{array}$ & -.116 & .108 & -.086 & -1.076 & .283 \\
\hline
\end{tabular}

a. Dependent Variable: Customers' relationship commitment

The above model summary 4 indicates that there remain a correlation between independent variables of Relational benefits (Confidence Benefit, Social Benefit, and Special Treatment Benefit) and dependent variable (Customers' 
relationship commitment). At 5\% significance level the correlation is $24.2 \%$. The value of adjusted R Square is 0.048. From ANOVA test, it can be remarked that there is a statistically significant effect of confidence benefit and social benefit on customers' retention because the significance level of these variables are less than $5 \%$ but there is no statistically significant effect of special treatment benefit because the significance level of these variables is greater than $5 \%$. Hence $\mathrm{H} 4_{0}$ is rejected and $\mathrm{H} 4_{\mathrm{a}}$ is accepted and the regressions equation will be:

$$
Y_{t}=a_{0}+b_{1} x_{1}+b_{2} x_{2}+\ldots \ldots \ldots+b_{n} x_{n}
$$

So, Customers' relationship commitment $=3.258+(.171)$ Confidence benefit+ (.208) Social benefit+ (-0.116) Special treatment benefit.

TABLE VII

\section{REGRESSION BETWEEN CUSTOMERS' RELATIONSHIP COMMITMENT AND DEVELOPMENT OF BANKING INDUSTRY.}

\begin{tabular}{l|c|c|c|r}
\hline \multicolumn{5}{c}{ Model Summary 5 } \\
\hline Model & $\mathrm{R}$ & R Square & $\begin{array}{c}\text { Adjusted R } \\
\text { Square }\end{array}$ & Std. Error of the Estimate \\
\hline 1 & & $.138^{\mathrm{a}}$ & .019 & \multicolumn{2}{c}{.015} & .13603 \\
\hline
\end{tabular}

a. Predictors: (Constant), Customers' relationship commitment.

\begin{tabular}{|c|c|c|c|c|c|c|}
\hline \multicolumn{7}{|c|}{ ANOVA $^{b}$} \\
\hline & Model & Sum of & df & Mean & $\mathrm{F}$ & Sig. \\
\hline \multirow[t]{3}{*}{1} & Regression & .094 & & .09 & 5.063 & $.025^{\mathrm{a}}$ \\
\hline & Residual & 4.811 & 26 & .01 & & \\
\hline & Total & 4.905 & 26 & & & \\
\hline
\end{tabular}

a. Predictors: (constant), Customers' relationship commitment

b. Dependent variable: Customers' relationship commitment is essential for development of banking industry

\begin{tabular}{l|c|c|c|c|c}
\hline \multicolumn{7}{c}{ Coefficients $^{\text {a }}$} \\
\hline \multirow{3}{*}{ Model } & \multicolumn{2}{|c|}{$\begin{array}{c}\text { Unstandardized } \\
\text { Coefficients }\end{array}$} & $\begin{array}{c}\text { Standardized } \\
\text { Coefficients }\end{array}$ & t & \multirow{2}{*}{ Sig. } \\
\cline { 2 - 4 } & B & Std. Error & Beta & & \\
\hline
\end{tabular}




\begin{tabular}{llllll}
\hline 1 & (Constant) & 1.115 & .043 & 25.658 & .000 \\
& Retention & -.023 & .010 & -.138 & -2.250 \\
\hline
\end{tabular}

a. Dependent Variable: Relationship commitment is essential for development of banking industry.

The above model summary 5 indicates that there remain a correlation between independent variables (Customers' relationship commitment) and dependent variable (Development of banking industry). At 5\% significance level the correlation is $13.8 \%$. The value of adjusted $\mathrm{R}$ Square is 0.015 . From ANOVA test, it can be remarked that there is a statistically significant effect of customers' retention on the development of banking industry because the significance level is less than $5 \%$. Hence $\mathrm{H} 5_{0}$ is rejected and $\mathrm{H} 5_{\mathrm{a}}$ is accepted and the regressions equation will be:

$$
Y_{t}=a_{0}+b_{1} x_{1}+b_{2} x_{2}+\ldots \ldots \ldots+b_{n} x_{n}
$$

So, Development of banking industry $=1.115+(-0.023)$ Customers' relationship commitment.

\section{CONCLUSIONS AND RECOMMENDATIONS}

Retaining customers has become a challenging job for the banks of Bangladesh in order to maintain a strong foothold in the banking industry. In our country the benefits of having long term customers was previously a neglected matter as marketers' main focus was earning profit by increasing sales. In our study we have focused on confidence benefits, social benefits and special treatment benefits that customers get from maintaining a long term relations with the banks. According to the results of the ranking importance of relational benefit the following recommendations are suggested for the banks of Bangladesh.

i. Banks should strictly maintain the procedure of protecting the client's privacy as the core of banking relation is confidentiality between banks and customers.

ii. The bank authority should create a friendly environment so that the customers feel relief from their anxiety as customers invest their money in the bank for security.

iii. Ranking importance of relational benefits has shown that honesty and reliability are the most important factors for customers' retention. So, the bank management should give special attention to select honest and friendly employees and should increase the reliability of service in order to retain the customers. 
iv. In the age of intense competition customers can get enough opportunity to evaluate the services of different competitive banks. So they will maintain their relation only with that bank which gives the best service than others. So, Banks should give more attention to redesign the services in order to retain the customers.

v. Customers feel better when the employees of bank recognize them at first sight. So to maintain long term relation; the bank should concentrate on recognizing capacity of the employees.

vi. Friendliness of the employees is a significant factor of customers' retention. So the banks should arrange special training program to develop a standard code of friendly attitude of all employees towards customers.

vii. Long term customers want service-related information more quickly than other customers. The banks can arrange special service desks for special customers so that the customers do not have to wait to get the service.

viii. The future of banking industry depends on maintaining long term profitable relations with the customers. So commercial banks should redesign their policies and strategies to retain their profitable customers. 


\section{REFERENCES}

Chen, P. T., \& Hu, H. H. (2010). The effect of relational benefits on perceived value in relation to customer loyalty: An empirical study in the Australian coffee outlets industry. International journal of hospitality management, 29(3), 405-412.

Chen, P. T., \& Hu, H. H. S. (2013). The mediating role of relational benefit between service quality and customer loyalty in airline industry. Total Quality Management \& Business Excellence, 24(9-10), 1084-1095.

Conze, O., Bieger, T., Laesser, C., \& Riklin, T. (2010). Relationship intention as a mediator between relational benefits and customer loyalty in the tour operator industry. Journal of Travel \& Tourism Marketing, 27(1), 51-62.

Dawkins, P. and Reichheld, F. (1990) "Customer Retention as a Competitive Weapon", Directors and Boards, vol 14, no 4, 1990

Gwinner, K. P., Gremler, D. D., \& Bitner, M. J. (1998). Relational benefits in services industries: the customer's perspective. Journal of the academy of marketing science, 26(2), 101-114.

Han, H., \& Kim, W. (2009). "Outcomes of relational benefits: restaurant customers'perspective". Journal of Travel \& Tourism Marketing, 26(8), 820835 .

Kim, W., \& Ok, C. (2009). The effects of relational benefits on customers' perception of favorable inequity, affective commitment, and repurchase intention in fullservice restaurants. Journal of Hospitality \& Tourism Research, 33(2), 227-244.

Kothari C.R. (2011). Research Methodology, Second Edition, New Delhi.

Molina, A., Martín-Consuegra, D., \& Esteban, Á. (2007). Relational benefits and customer satisfaction in retail banking. International Journal of Bank Marketing, 25(4), 253-271.

Patterson, P. G., \& Smith, T. (2001). Relationship benefits in service industries: a replication in a Southeast Asian context. Journal of Services Marketing, 15(6), 425-443.

Zeithmal, V. A. ,Binter, M. J., Gremler,D.D.,Pandit, A. (2011). Services Marketing. New Delhi: Tata McGraw Hill Education Private Limited.

\section{Websites}

www. scholar.google.com

en.wikipedia.org accessed on 22.03.2015. 


\section{APPENDIX}

TABLE I

\section{DEMOGRAPHIC CHARACTERISTICS OF THE RESPONDENTS}

\begin{tabular}{|c|c|c|c|}
\hline Characteristics & Category & Frequency & Percent \\
\hline \multirow[t]{5}{*}{ Age } & 21-30 Years & 28 & 10.7 \\
\hline & 31-40 Years & 52 & 19.8 \\
\hline & 41-50 Years & 68 & 26.0 \\
\hline & 51-60 Years & 63 & 24.0 \\
\hline & Above 60 Years & 51 & 19.5 \\
\hline \multirow[t]{4}{*}{ Gender } & Total & 262 & 100.0 \\
\hline & Male & 161 & 61.5 \\
\hline & Female & 101 & 38.5 \\
\hline & Total & 262 & 100.0 \\
\hline \multirow[t]{4}{*}{ Marital status } & Married & 157 & 59.9 \\
\hline & Unmarried & 93 & 35.5 \\
\hline & Others & 12 & 4.6 \\
\hline & Total & 262 & 100.0 \\
\hline \multirow[t]{3}{*}{ Types of Bank } & Conventional & 158 & 60.3 \\
\hline & Islamic & 104 & 39.7 \\
\hline & Total & 262 & 100.0 \\
\hline \multirow[t]{4}{*}{ Types of Account } & Current & 109 & 41.6 \\
\hline & Savings & 95 & 36.3 \\
\hline & Term & 58 & 22.1 \\
\hline & Total & 262 & 100 \\
\hline \multirow{6}{*}{$\begin{array}{l}\text { Experience of } \\
\text { Banking }\end{array}$} & One year & 6 & 2.3 \\
\hline & Two Years & 38 & 14.5 \\
\hline & Three Years & 79 & 30.2 \\
\hline & Four Years & 106 & 40.5 \\
\hline & More than four years & 33 & 12.6 \\
\hline & Total & 262 & 100.0 \\
\hline
\end{tabular}




\begin{tabular}{l|l|c|c}
\hline \multicolumn{1}{c|}{ Characteristics } & \multicolumn{1}{c|}{ Category } & Frequency & Percent \\
\hline Educational Level & SSC & 12 & 4.6 \\
& HSC & 33 & 12.6 \\
& Graduate & 90 & 34.4 \\
& Post Graduate & 89 & 34.0 \\
& M.Phil. / PhD. & 38 & 14.5 \\
& Total & $\mathbf{2 6 2}$ & $\mathbf{1 0 0 . 0}$ \\
Profession & Business man & 14 & 31.3 \\
& Teacher & 28 & 10.7 \\
& Service Holder & 50 & 19.1 \\
& Banker & 82 & 5.3 \\
& Housewife & 45 & 17.2 \\
& Student & 43 & 16.4 \\
& Total & $\mathbf{2 6 2}$ & $\mathbf{1 0 0 . 0}$ \\
& Below Tk 10,000 & 24 & 9.2 \\
& Tk.10,001-Tk. 20,000 & 39 & 14.9 \\
& Tk.20,001-Tk. 30,000 & 42 & 16.0 \\
& Tk.30,001-Tk. 40,000 & 91 & 34.7 \\
& Above Tk.40,000 & 66 & 25.2 \\
& Total & $\mathbf{2 6 2}$ & $\mathbf{1 0 0 . 0}$ \\
\hline
\end{tabular}

Source: Field Survey, February 2015 